\title{
Effects of Anthropogenic Events and Viral Persistence on Rodent Reservoirs of Hantavirus Infection: Understanding Host-Pathogen Interactions Facilitates Novel Approaches to Intervention Strategies
}

\author{
Abdullah Mahmud-Al-Rafat ${ }^{1,3}$, Mahbub-E-Sobhani ${ }^{1}$, Andrew W. Taylor-Robinson ${ }^{2, *}$ \\ ${ }^{1}$ Biotechnology and Genetic Engineering Discipline, Khulna University, Khulna, Bangladesh \\ ${ }^{2}$ School of Medical \& Applied Sciences, Central Queensland University, Rockhampton, Australia \\ ${ }^{3}$ Research and Development Department (R\&D), Incepta Vaccine Limited. Dewan Idris Road, Jirabo, Savar Dhaka, Bangladesh \\ *Corresponding author: a.taylor-robinson@cqu.edu.au
}

Received March 29, 2015; Revised April 07, 2015; Accepted April 12, 2015

\begin{abstract}
Hantaviruses are primarily rodent-borne pathogens which have received considerable attention recently due to their high mortality rates in humans. In order to find the causes of rapid transmission and emergence of hantavirus-associated diseases anthropogenic changes are a priority. These include deforestation, urbanization, noise pollution, light pollution and electromagnetic fields, all of which have been shown to profoundly affect rodent physiology and immunology. Moreover, anthropogenic events promote human-rodent co-habitation and thereby provide a driver to increase rates of transmission and, by extrapolation, levels of infection in humans. Such environmental disruption acts as a chronic stressor to rodents and causes elevated concentrations of glucocorticoids, which are a major class of immunosuppressive hormone. Glucocorticoids are responsible for altering the immune tolerance of rodents, thereby rendering them susceptible to infection. Glucocorticoids induce regulatory $\mathrm{T}$ lymphocytes to reduce inflammatory and antiviral responses and to activate regulatory responses, principally through production of the cytokines interleukin- 10 and transforming growth factor- $\beta$ to support viral persistence. In order to develop a low-cost intervention strategy for hantavirus infection consideration should be given to a systemic approach to therapy. This would both aim to achieve a reduction of anthropogenic stressors and to gain a greater understanding of host-pathogen interactions.
\end{abstract}

Keywords: hantavirus, rodent, reservoir, viral persistence, anthropogenic event, glucocorticoid, regulatory $T$ lymphocyte, anti-viral

Cite This Article: Abdullah Mahmud-Al-Rafat, Mahbub-E-Sobhani, and Andrew W. Taylor-Robinson, "Effects of Anthropogenic Events and Viral Persistence on Rodent Reservoirs of Hantavirus Infection: Understanding Host-Pathogen Interactions Facilitates Novel Approaches to Intervention Strategies.” American Journal of Infectious Diseases and Microbiology, vol. 3, no. 2 (2015): 77-86. doi: 10.12691/ajidm-3-2-4.

\section{Introduction}

Developing strategies to counter the emergence and reemergence of infectious diseases has been the subject of an appreciable research effort over recent decades [1]. Currently, three-quarters of emerging human infectious diseases are caused by zoonotic pathogens, i.e. those that are transmitted naturally between vertebrate animals and humans, often through the agency of a vector or fomite $[2,3]$. At present, rodents are known to be a reservoir to more than 60 human-infecting viruses, including hantaviruses, the subject of this review, but also lymphocytic choriomeningitis virus, plague and leptospirosis [4,5]. Hence, control of rodents in situations of co-habitation with humans is a public health priority. Whereas rodents, the normal host of hantaviruses, show no signs of disease, infection in humans is severe and may be fatal $[6,7]$.
Although anthropogenic stresses, caused by humans, are recognized as a major driving force to facilitate the recent repeated breakout of infectious diseases from wildlife reservoirs [8,9], neither the impact of such stressors nor their mechanism of action has been studied [10]. The emergence of hantaviruses could also be attributed to anthropogenic stressful events [8]. Several anthropogenic factors, for example deforestation, urbanization, noise and light pollution, and electromagnetic fields, contribute to the alteration of endocrine balance in rodents. These stressors are also responsible for immune, nervous and physiological alterations [11]. Rodents that are exposed to chronic anthropogenic stress are reported to have elevated levels of glucocorticoids (GCs) [12], a major class of immunosuppressive steroid hormone released from the adrenal gland [13]. Interactions between endocrine, nervous and immune systems play a major role in determining the outcome of host-pathogen interactions 
[14]. GCs are responsible for reducing the resistance of wild animals to viruses and increase their tolerance to harbouring the virus in a minimal range without causing any disease [15]. The possibility has been suggested that by activating organ-specific regulatory mechanisms GCs also influence the host-pathogen interaction $[16,17]$.

In this review, hantavirus-associated disease symptoms and their epidemiology, current treatment, prevention and vaccine development are discussed. We describe the mechanism of viral persistence in rodents driven by glucocorticoid hormone and also shed light on different types of anthropogenic events thought to play a role in facilitating the emergence and transmission of hantavirusassociated diseases in urban areas. An understanding of the chronicity of hantavirus infection in rodents, and its transmission to humans, would prove valuable to control programs for treating newly emerging and reemerging infectious diseases.

\section{Transmission and Epidemiology}

Hantaviruses are negative-sensed, enveloped, single stranded RNA viruses that belong to the genus Hantavirus and family Bunyaviridae. This family includes four other genera (Nairovirus, Orthobunyavirus, Phlebovirus and Tospovirus) with about 330 species currently recognized [18]. The precise number of hantavirus species to be identified is a matter of debate, but over 20 distinct viral species exist in nature; at least 11 are associated with human disease.

Table 1. Geographical Distribution of Pathogenic Hantaviruses with their Natural Reservoirs

\begin{tabular}{|c|c|c|c|}
\hline Hantavirus Serotype & Associated Clinical Syndrome & Natural Reservoir & Geographical Distribution \\
\hline Amur & HFRS & $\begin{array}{l}\text { Apodemus peninsulae } \\
\text { (Korean field mouse) }\end{array}$ & $\begin{array}{c}\text { Far east Russia, Southeast Siberia, } \\
\text { Northeast China, South Korea }\end{array}$ \\
\hline Dobrava-Af & HFRS & $\begin{array}{c}\text { Apodemus flavicollis } \\
\text { (Yellow-necked field mouse) }\end{array}$ & Central Europe, European Russia \\
\hline Dobrava-Aa & HFRS & $\begin{array}{c}\text { Apodemus agrarius } \\
\text { (Striped field mouse) }\end{array}$ & Central and Eastern Europe \\
\hline Puumala & NE, a type of HFRS & $\begin{array}{c}\begin{array}{c}\text { Clethrionomys glareolus } \\
\text { (Red bank vole) }\end{array} \\
\end{array}$ & Europe-wide \\
\hline Seoul & HFRS & $\begin{array}{c}\text { Rattus norvegicus, Rattus rattus (Brown } \\
\text { rat, black rat) }\end{array}$ & Worldwide \\
\hline Tula & HFRS & $\begin{array}{c}\text { Microtus arvalis } \\
\text { (Common vole) }\end{array}$ & Northern and Eastern Europe \\
\hline Hantaan & HFRS & $\begin{array}{l}\text { Apodemus agrarius } \\
\text { (Striped field mouse) }\end{array}$ & Central Europe, Korea, China, Taiwan \\
\hline Andes Oran & HPS & $\begin{array}{l}\text { Oligoryzomys longicaudatus } \\
\text { (Long-tailed pygmy rice rat) }\end{array}$ & Argentina, Chile, Uruguay \\
\hline Araraquara & HPS & $\begin{array}{c}\text { Bolomys lasiurus } \\
\text { (Hairy-tailed bolo mouse) }\end{array}$ & Brazil \\
\hline Bermejo & HPS & $\begin{array}{l}\text { Oligoryzomys chacoensis } \\
\text { (Chacoan pygmy rice rat) }\end{array}$ & Northwest Argentina \\
\hline $\begin{array}{c}\text { Black Creek } \\
\text { Canal }\end{array}$ & HPS & $\begin{array}{l}\text { Sigmodon hispidus } \\
\text { (Hispid cotton rat) }\end{array}$ & USA (Florida) \\
\hline $\begin{array}{c}\text { Castelo dos } \\
\text { Sonhos } \\
\end{array}$ & HPS & - & Brazil \\
\hline Choclo & HPS & $\begin{array}{l}\text { Oligoryzomys fulvescens } \\
\text { (Fulvous pygmy rice rat) }\end{array}$ & Panama \\
\hline Нu39694 & HPS & - & Argentina \\
\hline Juquitiba & HPS & $\begin{array}{c}\text { Oligoryzomys nigripes } \\
\text { (Black-footed pygmy rice rat) }\end{array}$ & Brazil \\
\hline Laguna Negra & HPS & $\begin{array}{l}\text { Calomys laucha } \\
\text { (Vesper mouse) }\end{array}$ & Bolivia,Paraguay \\
\hline Lechiguanas & HPS & $\begin{array}{l}\text { Oligoryzomys flavescens } \\
\text { (Yellow pygmy rice rat) }\end{array}$ & Argentina \\
\hline Maciel & HPS & $\begin{array}{l}\text { Necromys benefactus } \\
\text { (Dark field mouse) }\end{array}$ & Argentina \\
\hline Sin Nombre & HPS & $\begin{array}{c}\text { Peromyscus maniculatus } \\
\text { (Deer mouse) }\end{array}$ & USA, Canada \\
\hline New York & HPS & $\begin{array}{l}\text { Peromyscus leucopus } \\
\text { (White-footed mouse) }\end{array}$ & USA \\
\hline Rio Mamore & HPS & $\begin{array}{c}\text { Neacomys spinosus } \\
\text { (Common bristly mouse) } \\
\end{array}$ & Bolivia \\
\hline Oran & HPS & $\begin{array}{l}\text { Oligoryzomys longicaudatus } \\
\text { (Long-tailed pygmy rice rat) }\end{array}$ & Northern Argentina \\
\hline Monongahela & HPS & Peromyscus maniculatus (Deer mouse) & Eastern USA \\
\hline
\end{tabular}

The transmission of hantaviruses involves the transfer of virus to humans from a typically disease-free hantavirus-associated rodent host. The geographical distribution of each species is dependent upon the regional location of its reservoir host, that which serves as a source of infection and potential reinfection of humans and as a means of sustaining the pathogenlong-term (Table 1) [19]. Humans may become infected after coming into contact with hantavirus-infected rodent egestion, excretions and secretions, or soiled nesting material. This is most commonly through airborne transmission via inhalation of aerosols containing the virus [20,21]. Persons dwelling in confined spaces that contain fresh droppings, urine or saliva from infected rodents place themselves at risk of becoming infected [22]. Interpersonal transmission is very uncommon with the noted exception of Andes virus [23]. 
Similar negative-stranded RNA viruses, such as Ebola and Marburg, can be transmitted by contact with infected human blood and body fluids, and are known to spread to patient care workers in African hospitals [24]. These viruses, however, do not transfer readily in a modern hospital setting implementing universal precautions. In general, droplet and/or fomite transfer has not been demonstrated for hantaviruses in either the haemorrhagic or pulmonary forms.

Recognized risk factors for transmission include the presence of rodents and rodent excreta in the proximity of domestic and work place buildings. In endemic areas particular problems are associated with summer cottages that have poor ventilation and with farmhouses on land with abundant rodent populations [19,25,26,27]. Longterm residential stay for work or military service in forests with a high prevalence of hantavirus-infected rodents also poses a significant risk of transmission [26,28,29]. In Europe and Asia the most reported cases of hantavirus infection come from Russia and China, respectively [30,31]. Ecological disturbances play a crucial role in hantavirus transmission. Reduction of the natural habitat of a reservoir host combined with loss of biodiversity promotes migration of infected rodents into areas of human habitation. This has the effect of further increasing the rate of pathogen transmission $[19,32]$.

\section{Evolution of Hantaviruses}

It was long since thought that hantaviruses have coevolved with their rodent host $[33,34]$, but the concept of co-divergence is supported by recent evidence of host switching, i.e. cross-species transmission, followed by local host adaptation [35]. Increasing evidence suggests that in addition to rodents, shrews and moles also serve as hosts for hantaviruses [35,36,37,38].

Phylogenetic analysis suggests that ancestral soricomorphs, consisting of five families -Soricidae (shrews), Talpidae (moles), Solenodontidae (solenodons), Erinaceidae (hedgehogs and gymnures) and Nesophontidae (now extinct West Indies shrews) - may be the original mammalian hosts for hantaviruses [39]. Hantaviruses are unique in being the only known genus of Bunyaviridae which maintain rodent hosts, with all other viruses in this family carried by insects or arthropods. This lends credibility to the view that present day hantaviruses may have arisen from invertebrate-borne vectors as for other members of the Bunyaviridae [38]. Another recent study showed that hantaviruses share a mixed evolutionary history of infection of both shrews and rodents instead of being monophyletic with rodents, which is of direct relevance to the host switching event [37]. Care should be taken to distinguish shrews and moles from rodents as they differ in many characteristics, such as evolution, taxonomic order and lifespan, while at the same time sharing the common trait of inhabiting the same environmental communities, which sheds light on our understanding of host switching. This could occur following inter- or intra-species wounding or by virus shedding in respiratory secretions or excretions within the same ecological niche $[35,40]$. Immunologically-based mechanisms of persistence of hantaviruses in shrews and moles appear similar to those which are thought to have occurred in rodents throughout evolutionary history [41].

\section{Hantavirus-Associated Major Clinical Syndromes}

Hantaviruses show no clinical symptoms in rodents while humans, considered an unnatural dead-end host for infection, are susceptible to two distinct manifestations of hantavirus-associated clinical disease, haemorrhagic fever with renal syndrome (HFRS) and hantavirus pulmonary syndrome (HPS). The name hantavirus comes from the Hantan River region of South Korea, for which Hantaan virus, the cause of Korean haemorrhagic fever that was first isolated in the late 1970s, is named [4]. During the Korean War (1950-1953) more than 3,000 United Nations soldiers were infected with Korean haemorrhagic fever, now referred to as HFRS. Another notable outbreak during 1993 in the 'Four Corners' region of the Southwestern United States was associated with HPS [42].

HFRS and HPS share some common clinical signs. These include increased vascular permeability with hypotension, haemoconcentration, overexpression of $\mathrm{CD}^{+} \mathrm{T}$ lymphocytes and sometimes elevated leukocyte levels in peripheral blood [43]. While the name HFRS indicates a renal involvement with haemorrhagic fever, its clinical development is divided into five distinct stages: febrile; hypotensive; oliguric; diuretic and convalescent. A usual fatality rate due to HFRS in humans of $5-20 \%$ is widely recognized [44]. In some cases, it has been known to cause permanent renal failure. Facial flushing and conjunctival injection are initial signs of HFRS, followed by high fever, backache, abdominal pain, photophobia and pharyngeal enanthem. Febrile stage symptoms arise usually 2-3 weeks after exposure and typically occur for 3-7 days. The hypotensive stage follows onset of fever and involves a drop in blood pressure due to vascular leakage. Reduced kidney function causes abnormal urinary sediment. The onset of renal failure and proteinuria, together with severe abdominal or back pain, is observed in the oliguric phase. The diuretic phase, characterized by the passing of 3-6 litres of urine per day, begins from day 11 and can last for a couple of days to weeks. Symptoms improve as recovery occurs during the convalescent phase, which lasts from weeks to several months [43,44].

HPS is noted for influenza-like symptoms including high fever, headache, myalgia and shortness of breath [45]. Hypotension and acute non-cardiac pulmonary oedema may develop within 2-15 days. Neutrophilic leukocytosis and haemoconcentration are also observed. HPS can deteriorate rapidly into acute respiratory failure and, despite mechanical ventilation and intervention with potent diuretics, is characterized by a high mortality rate of approximately 50\% [44,46].

\section{Anthropogenic Stresses in Urban Areas and their Effects on Rodents}

A man-made disturbance of the natural environment is known as an anthropogenic event, which results in stress to wild animals. This has been identified as a key factor in 
the advent of emerging infectious diseases (EIDs) in wildlife but has not been studied in detail [10]. Although hantaviruses have persisted in rodents for thousands of years, the advent of civilization has increasingly brought about chronic anthropogenic events which are thought to promote more efficient transmission of the virus and thereby the emergence of hantavirus-associated diseases [47]. Here, we discuss several classes of anthropogenic events most common in urban areas, including deforestation, urbanization, noise pollution, light pollution and electromagnetic fields, and evaluate how each affects rodent physiology and immunity. These effects probably facilitate the rapid transmission of hantaviruses in urban areas.

\subsection{Effects of Deforestation and Urbanization}

The rate of urbanization by human populations is escalating rapidly which favours direct human dominance over nature in environments in which deforestation is a common event. Since urbanization is correlated positively with loss of biodiversity, this influences shift and migration of host, vector, food competition and, most importantly, host-pathogen ecology [48,49]. A high level of biodiversity is responsible for a reduction of pathogen transmission while anthropogenic factors are found to decrease diversity and to increase pathogen transmission risk [32]. Landscape fragmentation increases rodent population density in areas of high food competition, which consequently brings rodents into close contact with humans. This supports inter- or intra-species transmission and a high prevalence of viruses [50,51]. Effects of urbanization, such as habitat fragmentation, deforestation and food scarcity leading to increased feeding competition, act as chronic stressors for rodents. This results in rapid physiological changes and lower immunity to viruses, which is mediated by GCs [52,53].

\subsection{Effects of Noise}

Noise pollution is identified as a source of anthropogenic stressors to urban animals. Significant levels of physiological changes occur in those rodents that are exposed to noise, while no such changes are observed in rodents in fields with little outside sound [54,55]. Changes in physiological and behavioral responses in rodents due to noise effects may be characterized by an elevated level of corticosterone, immune alteration, a decrease in reproductive function, reduced body weight and reduced gastric secretion. Noise pollution also has profound effects on the rodent nervous system. This may be demonstrated by subjecting rodents to conditions of either noise or quiet. When rats were subjected to an electronically generated noise stimulus of $10 \mathrm{~Hz}$ to $10 \mathrm{kHz}$ at a specific time every morning for 3 weeks, they developed an attenuation of their parasympathetic nervous system while their sympathetic nervous system remained unchanged [54]. Intestinal mucosa of rats exposed to high levels of noise developed significant inflammation compared to the gut of rats kept in quiet conditions. Furthermore, rats subjected to loud noise were found to have a reduced humoral immune response and phagocytic activity and also showed a decreased number of $\mathrm{T}$ lymphocytes [56].

\subsection{Effects of Artificial Lighting}

Humans first started to interfere with the natural daynight cycle following the discovery of fire. This increased over the last century with the invention of artificial lighting, which escalated to the extent of now causing what we recognize as 'light pollution'. Rapid urbanization is further intensifying levels of artificial light at night in metropolitan areas where the night sky is always lit as if by a full moon[57,58]. Exposure to continuous artificial light at night can suppress the rhythmicity of circadian activity, body temperature and initiate sleep deprivation in rodents, which has the potential to modulate the immune system [59,60,61]. Sleep deprivation further activates the hypothalamic-pituitary-adrenal (HPA) axis and may alter the consequent stress response [62]. The balance of several hormones, including GCs, prolactin, adrenocorticotropic-releasing hormone, corticotrophinreleasing hormone, serotonin and melatonin, is altered by the constant light or light-light cycle. Continuous low level artificial light at night is identified as reducing melatonin production in rodents and this phenomenon could suppress immunostimulation [60,63]. Increased concentrations of plasma corticosterone are observed in male mice under conditions of prolonged artificial lighting, which is an indicator of stress [64,65]. Artificial lighting is also responsible for suppression of cell-mediated and humoral immune responses in rodents [61]. These findings collectively suggest potential harmful effects of disrupting natural lighting by introducing artificial light. In contrast, environmentally-attached species, those which are not exposed to artificial lighting, do not show any sign of these physiological or immunological changes [65].

\subsection{Effects of Electromagnetic Fields}

The absolute dependence on electricity in the daily lives of people resident in developed nations and, increasingly, in developing nations means that globally humans discharge a significant level of electromagnetism into the environment. In this age of widespread electrification we are surrounded by transformers, power lines, mobile telephone signal transmitters, radio waves, microwaves and electronic devices, the activities of which generate electromagnetic fields (EMFs). The correlative evidence that extremely low frequency (ELF) EMFs are a health hazard has become a matter of great concern in recent decades [66,67]. City dwellers have considerable exposure to ELF magnetic flux on a daily basis. Leakage of stray current is the most common source of magnetic flux in urban environments [68]. In most countries, electrical power is generated at an ELF-EMF frequency of 50/60 Hz. The flow of alternating current generates a low level EMF. Several reports have suggested that long-term exposure to ELF-EMF induces elevated levels of plasma corticosterone and depressive-like behaviours in rodents $[69,69,71]$. Continuous exposure of rodents to ELF-EMF promotes a state of chronic stress and triggers activation of the HPA axis [71]. Another recent report provided evidence that rats exposed to EMF have significantly higher levels of corticosterone than do control animals [72]. Chronic low power density microwaves have also been shown to increase corticosterone concentrations in rats [73]. EMF-mediated chronic stress and an elevated persistence of GCs are causally linked toa significant 
reduction of mononuclear cells, especially $\mathrm{CD}^{+} \mathrm{T}$ lymphocytes. Production of interleukin (IL)-2 is also decreased. All these events result in suppression of cellular immunity in rats $[74,75]$.

\section{Anthropogenic Events Promote Human-Rodent Co-Habitation to Increase Prevalence of Infection}

From the above discussion it is apparent that anthropogenic events are responsible directly or indirectly for infectious disease outbreaks like hantaviruses. These may be considered as provoking rodent migration into areas of human dwelling while simultaneously causing suppression of rodent immunity to viruses to render them more suitable reservoir hosts. It is noteworthy that anthropogenic events not only play an important role in disease occurrences but, conversely, are thus a consideration for approaches to disease prevention. By restricting anthropogenic events it may be possible to reduce human-rodent co-habitation and thereby contribute to more effective disease control management.

GCs are secreted by an animal when it detects a stressor and are responsible for initiation of a stress response. Acute stress, commonly known as the 'flight-or-flight' response, is characterized by induction of the catecholamine hormones epinephrine (adrenaline) and norepinephrine (noradrenaline), whereas chronic stress is distinguished by release of the GC hormones cortisol and corticosterone. Of the two, corticosterone is found more abundantly among rodents although some species appear to express both $[76,77]$. The mammalian immune system has two unique properties termed 'resistance' and 'tolerance' whereby resistance mechanisms are directed specifically towards a pathogen to limit its burden while tolerance mechanisms are concerned with reducing the indirect impact of a given infection by neutralizing the effects of toxins and metabolic byproducts produced by the associated pathogen [78]. GCs are responsible for reducing resistance and elevating tolerance, thereby supporting viral persistence [14]. It is well known that the endocrine, nervous and immune systems all interact to regulate the fate of host-pathogen interactions $[79,80]$. Most hantavirus outbreaks occur in those areas where the environment is extensively disturbed due to anthropogenic changes and rodents experience chronic anthropogenic stresses [8]. Since chronic stress is responsible for increasing an animal's susceptibility to infection [81], this is a likely reason why viral infections are more prevalent in urban animals than in their rural counterparts [52].

We suggest that due to the immunosuppressive activity of GCs it is possible that urban rodents, exposed to considerable and varied stresses, have a greater prevalence of hantavirus infection than do rodents resident in a less stressful rural environment. Hence, the heightened susceptibility of urban rodents to virus transmission due to enforce dgreater contact with humans may be causally linked to increased hantavirus outbreaks in populated areas. A comparison of the microbial burden of rodents from wild and urban dwellings is justified. A recent study of urban-dwelling Norway rats identified the presence of novel viruses besides hantaviruses [82]. This is a possible indication of a difference in wild and urban rodents' viral loads.

\section{Mechanism of Hantavirus Persistence in Rodents}

The mechanism by which rodents support hantavirus infection without showing any signs of disease is just starting to be revealed. The study of host-pathogen interactions is a recently established field of virology research with the potential to provide insight into how a host maintains viruses without clinical signs, which may inform future antiviral therapies. Generally, viruses are considered to follow one of two strategies for survival: 'hit and run'; 'hit and stay'. Regarding infection of rodents, hantaviruses follow the hit and stay strategy. In order to establish persistent infection a hantavirus must not show any cytopathic effect towards its host and must escape from host immune defence. Although naturally hosts do not benefit from harbouring viral infection, depending on the environment a commensal state may be established [83].

The enzyme matrix metalloproteinase 9 (MMP-9), known to disrupt the endothelial membrane and extracellular matrix in normal physiological processes, is elevated by hantavirus infection of monocytes and macrophages. This enables hantaviruses to gain the access required to disseminate into tissue. This is necessary only to achieve a high viral load in rodent lungs and not for viral persistence; expression of MMP-9 is reduced when infection is established [84]. Expression of pattern recognition receptors in lungs [85] and antigen-presenting molecules, e.g. MHC class II, is reduced following hantavirus infection in rats, indicating their contribution to persistence of infection $[86,87]$. Clinical manifestations in hantavirus-infected humans are thought to be due to excessive pro-inflammatory and $\mathrm{CD}^{+} \mathrm{T}$ lymphocyte responses while rodents demonstrate reduced proinflammatory and antiviral responses and increased regulatory responses in persistent hantavirus infection $[44,88]$. During chronic infection, expression of antiviral interferon (IFN)- $\beta$, IFN- $\gamma$ and pro-inflammatory cytokines is reduced $[85,88]$. Expression in vitro of the Hantaan virus (HTNV) resistance protein Mx2 is also suppressed during Seoul virus (SEOV) infection [89,90]. Increased hantaviral load and mortality are both observed in $\mathrm{CD}^{+} \mathrm{T}$ lymphocyte-deficient rats, indicating that these immune cells play a crucial role in suppressing hantavirus replication and host infection; therefore, to establish a persistent infection hantaviruses must evade $\mathrm{CD}^{+} \mathrm{T}$ lymphocyte-mediate immunity [43,91,92].

Regulatory $\mathrm{T}\left(\mathrm{T}_{\mathrm{reg}}\right) \mathrm{CD}^{+} \mathrm{CD} 25^{+}$lymphocytes act to suppress pro-inflammatory and $\mathrm{CD}^{+} \mathrm{T}$ cell activity to maintain host homeostasis and thereby enable hantaviral persistence (Figure 1) [93]. Inactivation of $\mathrm{T}_{\text {reg }}$ lymphocytes reduced expression of SEOV RNA in rat lungs, which is a clear indication of $\mathrm{T}_{\text {reg }}$ involvement in virus persistence [16,94].During chronic infection $T_{\text {reg }}$ lymphocytes suppress synthesis of tumour necrosis factor (TNF)- $\alpha$ and inflammatory responses and promote expression of transforming growth factor (TGF)- $\beta$, IL-10 and FoxP3 [16,95]. T helper (Th) $1 \mathrm{CD}^{+}$lymphocytes express IFN- $\gamma$, IL-2 and TNF- $\alpha$ and facilitate the cell- 
mediated immune activity of $\mathrm{CD}^{+} \mathrm{T}$ lymphocytes, natural killer (NK) cells and macrophages [96], while Th2 lymphocytes express IL-4, IL-5, IL-10 and IL-13, and promote antibody-mediate immunity [97]. $\mathrm{T}_{\text {reg }}$ lymphocytes, mediated by FoxP3, may initiate Th1-Th2 lymphocyte pathway polarization [98] and could also suppress the activity of antigen-presenting cells, such as macrophages and dendritic cells (DC), and B lymphocytes $[99,100]$. DC, which secrete TNF- $\alpha$ and IFN- $\alpha$, are also susceptible to hantavirus infection. However, immature or tolerogenic DC may activate $\mathrm{T}_{\text {reg }}$ lymphocytes through the mediation of TGF- $\beta$ to exert suppressive activity $[7,100,101]$. Antibodies specific for hantaviruses are not able to eliminate the virus, but after infection they remain detectable throughout life [84,102]. Infants acquire maternally-derived antibodies for the first two months following birth, which provide some protection [103,104].

GCs are capable of reducing host resistance to viruses and facilitate viral persistence by increasing tolerance to infection. When challenged by chronic anthropogenic stressors, immunologically suppressed rodents express elevated levels of GCs which mediate an organ-specific regulation that supports tolerance while removing resistance to hantavirus infection [15]. GCs block inflammatory pathways and induce apoptosis mediated by $\mathrm{T}_{\text {reg }}$ lymphocytes $[17,105,106,107]$. GCs not only suppress differentiation of DC but also induce production of tolerogenic DC which express elevated IL-10 and TGF- $\beta$. Such tolerogenic DC are responsible for generation and activation of $\mathrm{T}_{\text {reg }}$ lymphocytes to exert a regulatory control over $\mathrm{CD}^{+}$lymphocyte-mediated antiviral responses (Figure 1) [108,109,110,111]. GCs cause a polarization of $\mathrm{CD}^{+}$lymphocyte subsets from Th1 to Th2 and increase production of Th2 cytokines which further stimulate alternatively activated M2 macrophages [109,111,112,113]. M2 macrophages are characterized by excessive synthesis of IL-10 and TGF- $\beta$, which is triggered mainly by elevated levels of GCs which suppress activity of classically activated M1 macrophages [80,111,114,115]. High mortality rates attributable to an exaggerated proinflammatory response and efficient virus clearance are both observed in the absence of GCs, as demonstrated experimentally for other viral infections [116,117].This clearly indicates the critical function of GCs to viral persistence and in establishing an equitable balance in the host-pathogen interaction. This suggests that such GCoperated mechanisms as discussed above provide a regulatory feedback loop to protect the host against excessive immune response-associated pathology. Accordingly, we propose that GCs may playa pivotal regulatory role to support hantavirus persistence in rodents.

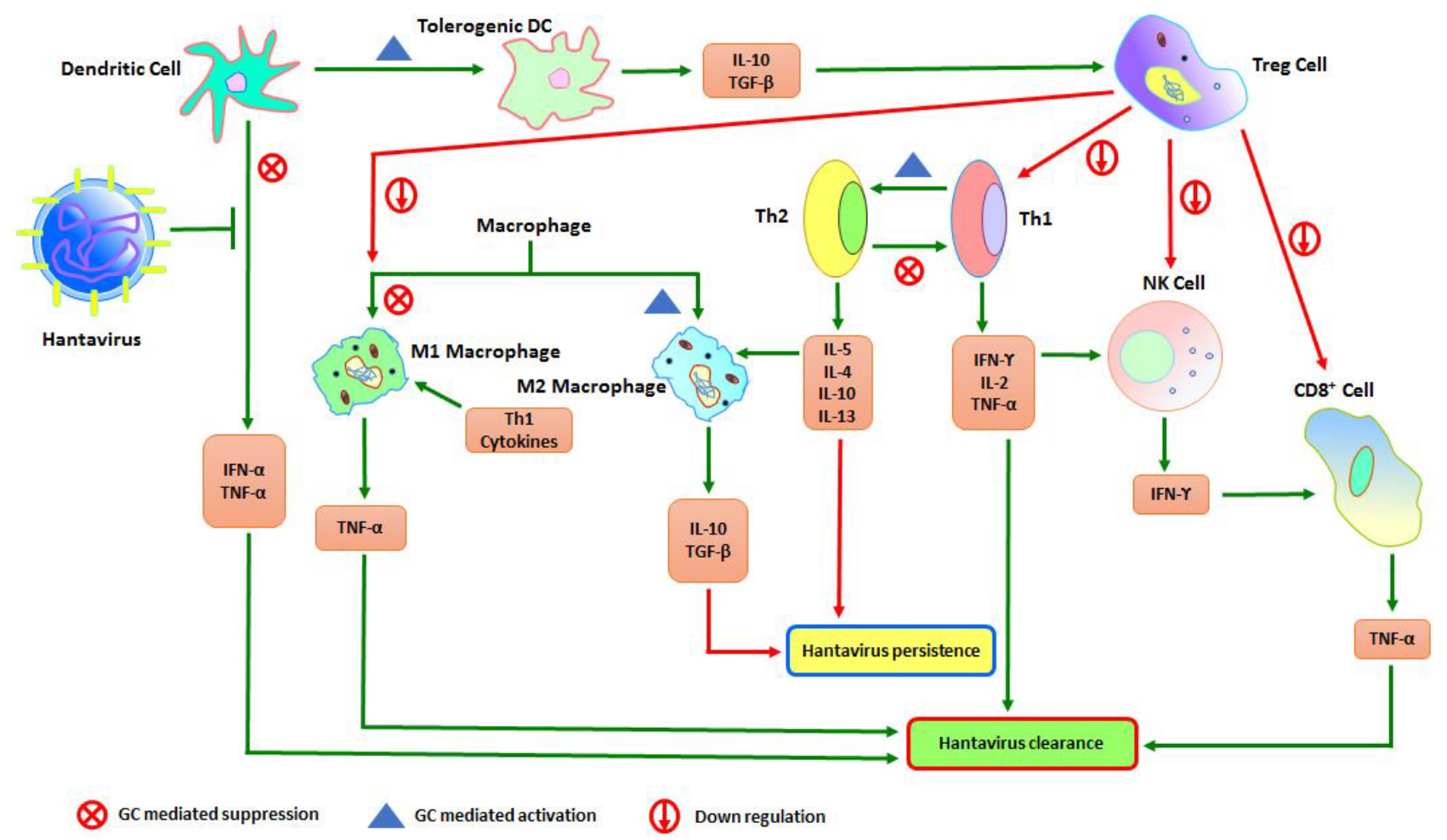

Figure 1. Cellular Immune Responses during Hantavirus Persistence in Rodents

\section{Approaches to Treatment and Prevention}

There is currently no drug that is approved by the US Food and Drug Administration for treatment of hantavirus infection. Ribavirin (1- $\beta$-D-ribofuranosyl-1,2,4-triazole-3carboxamide) has shown anti-hantaviral activity both in vitro and, to a lesser extent, in vivo. In murine models, ribavirin-treated animals exhibited higher survival rates $[118,119,120]$. However, clinical trials on ribavirin do not corroborate sufficiently such promising results to justify commercial development as an anti-hantaviral drug $[121,122]$.

The lack of specific treatment places an increased emphasis on preventative strategies aimed at minimizing rates of infection. Obviously, avoidance of contact with rodents and their excretions is the best way to prevent infection. Foodstuffs that are attractive to rodents should be kept in sealed containers and stored in small quantities 
in a domestic setting. Farmers who work on land with abundant rodent populations are recommended to wear a face mask in order to avoid inhalation of infectious material and thereby to minimize the risk of infection [19]. Seasonal residences should be well ventilated with fresh air before occupancy [44,123].

\section{Current Developments in Vaccine Research}

Although considerable effort has been applied to vaccine development against hantaviruses at present there is no efficacious vaccine therapy available for humans. Traditional vaccine approaches have been followed in Asia, including rodent brain- and cell culture-derived inactivated vaccines [124]. In particular, a mouse brainderived vaccine, Hantavax ${ }^{\circledR}$, was marketed commercially in Korea [125]. However, none of these vaccines has gained approval in the US for therapeutical use [126]. Studies with animal models show that these conventional inactivated vaccines derived from HTNV or SEOV would not protect against Puumala virus (PUUV) that is prevalent in Europe [127,128].

Current strategies are focused on developing a DNA vaccine to elicit neutralizing antibodies against hantavirus glycoproteins [129]. One approach is to prepare a single vaccine that would protect against multiple pathogenic hantavirus species. A recent study shows that a combination of plasmids from four pathogenic hantavirus species, HTNV, PUUV, Andes virus (ANDV) and Sin Nombre virus (SNV), could elicit comparable levels of neutralizing antibody against each species [130]. A combination of either HTNV and PUUV or ANDV and SNV provided only partial success. These preliminary findings indicate that a quadravalent vaccine could be a promising option for future anti-hantaviral vaccine research.

\section{Call for a Multidisciplinary Systemic Approach}

The emergence and reemergence of infectious diseases highlight the urgent need for effective public health surveillance and management systems. Rodents have developed an organ-specific tolerance mechanism mediated by GCs to promote their own survival. However, unplanned and unorganized urbanization is continuously increasing the fragmentation of habitats and the unwanted interactions of humans with infected wild species, which is attributable for the increasing appearance of EIDs. Research continues with the aim of elucidating fully the mechanism of viral persistence and the role of GCs in its regulation in rodents. Humans develop up-regulated proinflammatory responses against hantaviruses which, in rodents at least, are postulated to come under the control of GCs. There is some evidence to suggest that programmed cell death may be slow or absent from excessive immune responses in cases of human infection [7,131]. An in-depth understanding of hantavirus persistence may provide insights to inform the ongoing fight against hantavirusassociated diseases. It may be reasonably assumed that some features of immune evasion mechanisms are shared by all viruses. Therefore, an effective management system against infection with one virus species may provide a model for wider implementation as well as to direct strategic development of low cost therapies for future use.

\section{Conclusion}

For hantavirus infections, understanding and alleviating pathogenesis in humans affords only a partial view of a complex biological system that involves the pathogen and, potentially, both human and rodent hosts. In recent years, the suppressive effect of a stress response in humans has been clearly established but the effect(s) of stressors on other animals is far less known. In this respect, it can be argued that human negligence and poor management are major factors in the increased incidence of most EIDs. Humans, animals and their shared environment are all interlinked in a complex networked system. Therefore, future research should focus simultaneously on systemic and holistic approaches that consider molecular pathogenesis, virulence, endocrine and immune activities, host-pathogen interactions, vaccine targets, ecology and biodiversity. Without recognition of the interdependence of contributing factors, partial and fragmented insights gained from conventional approaches to research will not achieve consistent success in the fight against EIDs. In such circumstances, further hantavirus species may emerge, possibly involving different geographical areas and novel animal hosts.

\section{Acknowledgments}

We thank Prof. Dr. Morsaline Billah for his insightful comments during the preparation of this manuscript. The authors' research is supported by the Central Queensland University Health CRN and the Australian Government's Collaborative Research Networks Program.

\section{Conflict of Interest}

The authors declare no actual or potential conflicts of interest in relation to this article.

\section{Abbreviations}

GC glucocorticoid, HFRS haemorrhagic fever with renal syndrome, HPS hantavirus pulmonary syndrome, EID emerging infectious disease, HPA hypothalamicpituitary-adrenal, EMF electromagnetic fields, ELF extremely low frequency, MMP-9 matrix metalloproteinase 9, IFN interferon, HTNV Hantaan virus, SEOV Seoul virus, $T_{\text {reg }}$ regulatory $T$, TNF tumour necrosis factor, TGF transforming growth factor, IL interleukin, Th T helper, NK natural killer, DC dendritic cell, PUUV Puumala virus, ANDV Andes virus, SNV Sin Nombre virus, NE nephropathia epidemica (also known as epidemic nephropathy).

\section{References}


[1] van Doom HR. (2014). Emerging infectious diseases. Medicine 42, 60-63.

[2] Epstein PR. (1995). Emerging diseases and ecosystem instability: new threats to public health. Am J Public Health 85, 168-172.

[3] Rhyan JC, Spraker TR. (2010). Emergence of diseases from wildlife reservoirs. Vet Pathol 47, 34-39.

[4] Lee HW, Lee PW, Johnson KM. (1978). Isolation of the etiologic agent of Korean hemorrhagic fever. J Infect Dis 137, 298-308.

[5] Mills JN. (2006). Biodiversity loss and emerging infectious disease: An example from the rodent-borne hemorrhagic fevers. Biodiversity 7, 9-17.

[6] Ulrich R, Hjelle B, Pitra C, Krüger DH. (2002). Emerging viruses: the case 'hantavirus'. Intervirology 45, 318-327.

[7] Maes P, Clement J, Gavrilovskaya I, Van Ranst M. (2004) Hantaviruses: immunology, treatment, and prevention. Viral Immunol 17, 481-497.

[8] Jonsson CB, Figueiredo LT, Vapalahti O. (2010). A global perspective on Hantavirus ecology, epidemiology, and disease. Clin Microbiol Rev 23, 412-441.

[9] Clement J, Vercauteren J, Verstraeten WW, Ducoffre G, Barrios JM, Vandamme AM, Maes P, Van Ranst M. (2009). Relating increasing hantavirus incidences to the changing climate: the mast connection. Int J Health Geogr 8, 1.

[10] Daszak P, Cunningham AA, Hyatt AD. (2001). Anthropogenic environmental change and the emergence of infectious diseases in wildlife. Acta Trop 78, 103-116.

[11] Martin LB, Weil ZM, Nelson RJ. (2008). Seasonal changes in vertebrate immune activity: mediation by physiological trade-offs. Philos Trans R Soc Lond B Biol Sci 363, 321-339.

[12] McCabe PM, Sheridan JF, Weiss JM, Kaplan JP, Natelson BH, Pare WP. (2000). Animal models of disease. Physiol Behav 68, 501-507.

[13] Dickens MJ, Delehanty DJ, Romero LM. (2010). Stress: an inevitable component of animal translocation. Biol Cons 143, 1329-1341.

[14] Martin LB, Andreassi E, Watson W, Coon C. (2011). Stress and animal health: physiological mechanisms and ecological consequences. Nat Educ Knowl 3, 11.

[15] Al-Rafat AM, Taylor-Robinson AW. (2014). Emergence and persistence of hantavirus in rodent reservoirs: role of glucocorticoid hormone. Immun Dis 2, a9.

[16] Easterbrook JD, Zink MC, Klein SL. (2007). Regulatory T cells enhance persistence of the zoonotic pathogen Seoul virus in its reservoir host. Proc Natl Acad Sci USA 104, 15502-15507.

[17] Stary G, Klein I, Bauer W, Koszik F, Reininger B, Kohlhofer S, Gruber K, Skvara H, Jung T, Stingl G. (2011). Glucocorticosteroids modify Langerhans cells to produce TGF- $\beta$ and expand regulatory T cells. J Immunol 186, 103-112.

[18] Nichol ST, Beaty BJ, Elliott RM, Goldbach R, Plyusnin A, Schmaljohn CS, Tesh RB. (2005). Bunyaviridae. In: Virus Taxonomy, $8^{\text {th }}$ edn. Eighth Report of the International Committee on Taxonomy of Viruses (Amsterdam: Elsevier).

[19] Watson DC, Sargianou M, Papa A, Chra P, Starakis I, Panos G. (2013). Epidemiology of Hantavirus infections in humans: a comprehensive, global overview. Crit Rev Microbiol 40, 261-272.

[20] Zöller L, Faulde M, Meisel H, Ruh B, Kimmig P, Schelling U, Zeier M, Kulzer P, Becker C, Roggendorf M, Bautz EKF, Krüger DH, Darai G. (1995). Seroprevalence of hantavirus antibodies in Germany as determined by a new recombinant enzyme immunoassay. Eur J Clin Microbiol Infect Dis 14, 305-313.

[21] Deutz A, Fuchs K, Schuller W, Nowotny N, Auer H, Aspock H, Stunzner D, Kerbl U, Klement C, Kofer J. (2003). Seroepidemiological studies of zoonotic infections in hunters in southeastern Austria - prevalences, risk factors, and preventive methods. Berl Munch Tierarztl Wochenschr 116, 306-311.

[22] Hardestam J, Karlsson M, Falk KI, Olsson G, Klingström J, Lundkvist A. (2008). Puumala Hantavirus excretion kinetics in bank voles (Myodes glareolus). Emerg Infect Dis 14, 1209-1215.

[23] Wells RM, Sosa Estani S, Yadon ZE, Enria D, Padula P, Pini N, Mills JN, Peters CJ, Segura EL. (1997). An unusual hantavirus outbreak in southern Argentina: person-to-person transmission? Hantavirus Pulmonary Syndrome Study Group for Patagonia. Emerg Infect Dis 3, 171-174.

[24] Ftika L, Maltezou HC. (2013). Viral haemorrhagic fevers in healthcare settings. J Hosp Infect 83, 185-192.

[25] 25. Childs JE, Krebs JW, Ksiazek TG, Maupin GO, Gage KL, Rollin PE, Zeitz PS, Sarisky J, Enscore RE, Butler JC, Cheek JE,
Glass GE, Peters CJ. (1995). A household-based, casecontrol study of environmental factors associated with Hantavirus pulmonary syndrome in the southwestern United States. Am J Trop Med Hyg 52, 393-397.

[26] Crowcroft NS, Infuso A, Ilef D, Le Guenno B, Desenclos JC, Van Loock F, Clement J. (1999). Risk factors for human Hantavirus infection: Franco-Belgian collaborative case-control study during 1995-96 epidemic. Brit Med J 318, 1737-1738.

[27] Winter CH, Brockmann SO, Piechotowski I, Alpers K, an der Heiden M, Koch J, Stark K, Pfaff G. (2009). Survey and case control study during epidemics of Puumala virus infection. Epidemiol Infect 137, 1479-1485.

[28] Van Loock F, Thomas I, Clement J, Ghoos S, Colson P. (1999). A case-control study after a Hantavirus infection outbreak in the south of Belgium: who is at risk? Clin Infect Dis 28, 834-839.

[29] Mulic' R, Ropac D. (2002). Epidemiologic characteristics and military implications of hemorrhagic fever with renal syndrome in croatia. Croat Med J 43, 581-586.

[30] Tkachenko EA, Dzagurova TK, Bernshtein AD, Morozov VG, Slonova RA, Ivanov LI, Trankvilevskiı̌ DV, Kruger D. (2010). Hemorrhagic fever with renal syndrome in Russia in 21st century. In: VIII International Conference on HFRS, HPS and Hantavirus (Athens, Greece), p. 27 (abstract).

[31] Zhang Y, Zou Y, Fu Z, Plyusnin A. (2010). Hantavirus infections in humans and animals, China. Emerg Infect Dis 16, 1195-1203.

[32] Suzán G, Marcé E, Giermakowski JT, Mills JN, Ceballos G, Ostfeld RS, Armién B, Pascale JM, Yates TL. (2009). Experimental evidence for reduced rodent diversity causing increased Hantavirus prevalence. PLoS ONE 4, e5461.

[33] Plyusnin A, Morzunov SP. (2001). Virus evolution and genetic diversity of hantaviruses and their rodent hosts. Curr Top Microbiol Immunol 256, 47-75.

[34] Plyusnin A. (2002). Genetics of hantaviruses: implications to taxonomy. Arch Virol 147, 665-682.

[35] Kang HJ, Bennett SN, Dizney L, Sumibcay L, Arai S, Ruedas LA, Song JW, Yanagihara R. (2009). Host switch during evolution of a genetically distinct hantavirus in the American shrew mole (Neurotrichus gibbsii). Virology 388, 8-14.

[36] Arai S, Ohdachi SD, Asakawa M, Kang HJ, Mocz G, Arikawa J, Okabe N, Yanagihara R. (2008). Molecular phylogeny of a newfound hantavirus in the Japanese shrew mole (Urotrichus talpoides). Proc Natl Acad Sci USA 105, 16296-16301.

[37] Arai S, Bennett SN, Sumibcay L, Cook JA, Song J-W, Hope A, Parmenter C, Nerurkar VR, Yates TL, Yanagihara R. (2008). Phylogenetically distinct hantaviruses in the masked shrew (Sorex cinereus) and dusky shrew (Sorex monitcolus) in the United States. Am J Trop Med Hyg 78, 348-351.

[38] Kang HJ, Bennett SN, Sumibcay L, Arai S, Hope AG, Mocz G, Song JW, Cook JA, Yanagihara R. (2009). Evolutionary insights from a genetically divergent Hantavirus harbored by the European common mole (Talpa europaea). PLoS ONE 4, e6149.

[39] Yanagihara R, Gu SH, Arai S, Kang HJ, Song JW. (2014). Hantaviruses: rediscovery and new beginnings. Virus Res 187, 614.

[40] Ramsden C, Holmes EC, Charleston MA. (2009). Hantavirus evolution in relation to its rodent and insectivore hosts: no evidence for codivergence. Mol Biol Evol 26, 143-153.

[41] Vapalahti O, Lundkvist A, Fedorov V, Conroy CJ, Hirvonen S, Plyusnina A, Nemirov K, Fredga K, Cook JA, Niemimaa J, Kaikusalo A, Henttonen H, Vaheri A, Plyusnin A. (1999). Isolation and characterization of a Hantavirus from Lemmus sibiricus: evidence for host switch during Hantavirus evolution. $J$ Virol 73, 5586-5592.

[42] Nichol ST, Spiropoulou CF, Morzunov S, Rollin PE, Ksiazek TG, Feldmann H, Sanchez A, Childs J, Zaki S, Peters CJ. (1993). Genetic identification of a novel hantavirus associated with an outbreak of acute respiratory illness in the southwestern United States. Science 262, 914-917.

[43] Schönrich G, Rang A, Lütteke N, Raftery MJ, Charbonnel N, Ulrich RG. (2008). Hantavirus-induced immunity in rodent reservoirs and humans. Immunol Rev 225, 163-189.

[44] Muranyi W, Bahr U, Zeier M, van der Woude FJ. (2005). Hantavirus infection. J Am Soc Nephrol 16, 3669-3679.

[45] Sirotin BZ, Keiser NP. (2001). On the history of the study of haemorrhagic fever with renal syndrome in eastern Russia. Nephrol Dial Transplant 16, 1288-1289. 
[46] Beers MH, Berkow R. (2005). Infectious diseases; viral diseases. In: The Merck Manual of Diagnosis and Therapy, $17^{\text {th }}$ edn (Indianapolis: Wiley Publishers).

[47] McCabe PM, Sheridan JF, Weiss JM, Kaplan JP, Natelson BH, Pare WP. (2000). Animal models of disease. Physiol Behav 68, 501-507.

[48] Faeth SH, Warren PS, Shochat E, Marussich WA. (2005). Trophic dynamics in urban communities. Bioscience 55, 399-407.

[49] Shochat E, Warren PS, Faeth SH, McIntyre NE, Hope D. (2006). From patterns to emerging processes in mechanistic urban ecology. Trends Ecol Evol 21, 186-191.

[50] Mackelprang R, Dearing MD, St. Jeor S. (2001). High prevalence of Sin Nombre Virus in rodent populations, central Utah: a consequence of human disturbance? Emerg Infect Dis 7, 480-482.

[51] Goodin DG, Koch DE, Owen RD, Chu Y-K, Hutchinson JMS, Jonsson CB. (2006). Land cover associated with hantavirus presence in Paraguay. Glob Ecol Biogeogr 15, 519-527.

[52] Bradley CA, Altizer S. (2006). Urbanization and the ecology of wildlife diseases. Trends Ecol Evol 22, 95-102.

[53] Pergams ORW, Lawler JJ. (2009). Recent and widespread rapid morphological change in rodents. PLOS ONE 4, e6452.

[54] Baldwin AL. (2007). Effects of noise on rodent physiology. Int $J$ Comp Psychol 20, 134-144.

[55] Wright AJ, Soto AG, Baldwin AL, Bateson M, Beale CM, Clark C, Deak T, Edwards EF, Fernández A, Godinho A, Hatch L, Kakuschke A, Lusseau D, Martineau D, Romero LM, Wintle B, Weilgart L, Notarbartolo-di-Sciara G, Martin V. (2007). Anthropogenic noise as a stressor in animals: a multidisciplinary perspective. Int J Comp Psychol 20, 250-273.

[56] Kight CR, Swaddle JP. (2011). How and why environmental noise impacts animals: an integrative, mechanistic review. Ecol Lett 14, 1052-1061.

[57] Fonken LK, Finy MS, Walton JC, Weil ZM, Workman JL, Ross J, Nelson RJ. (2009). Influence of light at night on murine anxietyand depressive-like responses. Behav Brain Res 205, 349-354.

[58] Kyba CCM, Ruhtz T, Fischer J, Hölker F. (2011). Cloud coverage acts as an amplifier for ecological light pollution in urban ecosystems. PLOS ONE 6, e17307.

[59] Ikeda M, Sagara M, Inoue S. (2000). Continuous exposure to dim illumination uncouples temporal patterns of sleep, body temperature, locomotion and drinking behavior in the rat. Neurosci Lett 279, 185-189.

[60] Navara KJ, Nelson RJ. (2007). The dark side of light at night: physiological, epidemiological, and ecological consequences. $J$ Pineal Res 43, 215-224.

[61] Bedrosian TA, Fonken LK, Walton JC, Nelson RJ. (2011). Chronic exposure to dim light at night suppresses immune responses in Siberian hamsters. Biol Lett 7, 468-471.

[62] Meerlo P, Koehl M, van der Borght K, Turek FW. (2002). Sleep restriction alters the hypothalamic-pituitary-adrenal response to stress. J Neuroendocrinol 14, 397-402.

[63] Baydaş G, Erçel E, Canatan H, Dönder E, Akyol A. (2001). Effect of melatonin on oxidative status of rat brain, liver, and kidney tissues under constant light exposure. Cell Biochem Funct 19, 3741.

[64] Abílio VC, Freitas FM, Dolnikoff MS, Castrucci AM, FrussaFilho R. (1999). Effects of continuous exposure to light on behavioral dopaminergic supersensitivity. Biol Psychiatry 45, 1622-1629.

[65] Van der Meer E, Van Lool PL, Baumans V. (2004). Short-term effects of a disturbed light-dark cycle and environmental enrichment on aggression and stress-related parameters in male mice. Lab Animal 38, 376-383.

[66] Hardell L, Holmberg B, Malker H, Paulsson LE. (1995). Exposure to extremely low frequency electromagnetic fields and the risk of malignant diseases an evaluation of epidemiological and experimental findings. Eur J Cancer Prevent 4, Suppl 1, 3-107.

[67] Portier CJ, Wolfe MS. (1998). Assessment of health effects from exposure to power-line frequency electric and magnetic fields. NIEHS Working Group Report, North Carolina, Research Triangle Park.

[68] Lindgren M, Gustavsson M, Hamnerius Y, Galt S. (2001). ELF magnetic fields in a city environment. Bioelectromagnetics $22,87-$ 90.

[69] Bruyn de L, Jager de L. (1994). Electric field exposure and evidence of stress in mice. Environ Res 65, 149-160.

[70] Mostafa RM, Mostafa YM, Ennaceur A. (2002). Effects of exposure to extremely low frequency magnetic field of $2 \mathrm{G}$ intensity on memory and corticosterone level in rats. Physiol Behav 76, 589-595.

[71] Szemerszky R, Zelena D, Barna I, Bárdos G. (2010). Stressrelated endocrinological and psychopathological effects of shortand long-term $50 \mathrm{~Hz}$ electromagnetic field exposure in rats. Brain Res Bull 81, 92-99.

[72] Prochnow N, Gebing T, Ladage K, Krause-Finkeldey D, El Ouardi A, Bitz A, Streckert J, Hansen V, Dermietzel R. (2011). Electromagnetic field effect or simply stress? Effects of UMTS exposure on hippocampal longterm plasticity in the context of procedure related hormone release. PLOS ONE 6, e19437.

[73] Li M, Wang Y, Zhang Y, Zhou Z, Yu Z. (2008). Elevation of plasma corticosterone levels and hippocampal receptor translocation in rats: a potential mechanism for cognition impairment following chronic low-power-density microwave exposure. J Radiat Res 49, 163-170.

[74] Batuman OA, Sajewski D, Ottenweller JE, Pitman Dl, Natelson BH. (1990). Effects of repeated stress on T cell numbers and function in rats. Brain Behav Immun 4, 105-117.

[75] 75. Dhabhar FS, Miller AH, McEwen BS, Spencer RL. (1995). Effects of stress on immune cell distribution. Dynamics and hormonal mechanisms. J Immunol 154, 5511-5527.

[76] Romero LM, Butler LK. (2007). Endocrinology of stress. Int J Comp Psychol 20, 89-95.

[77] Busch DS, Hayward LS. (2009). Stress in a conservation context: a discussion of glucocorticoid actions and how levels change with conservation-relevant variables. Biol Cons 142, 2844-2853.

[78] Råberg L, Graham AL, Read AF. (2009). Decomposing health: tolerance and resistance to parasites in animals. Philos Trans $R$ Soc Lond B Biol Sci 364, 37-49.

[79] Dantzer R, O'Connor JC, Freund GG, Johnson RW, Kelley KW. (2008). From inflammation to sickness and depression: when the immune system subjugates the brain. Nat Rev Neurosci 9, 46-57.

[80] Martin LB, Hopkins WA, Mydlarz LD, Rohr JR. (2010). The effects of anthropogenic global changes on immune functions and disease resistance. Ann NY Acad Sci 1195, 129-148.

[81] Padgett DA, Glaser R. (2003). How stress influences the immune respon. Trends Immunol 24, 444-448.

[82] Firth C, Bhat M, Firth MA, Williams SH, Frye MJ, Simmonds P, Conte JM, Ng J, Garcia J, Bhuva NP, Lee B, Che X, Quan P-L, Lipkin WI. (2014). Detection of zoonotic pathogens and characterization of novel viruses carried by commensal Rattus norvegicus in New York City. mBio 5:e01933-14.

[83] Hilleman MR. (2004). Strategies and mechanisms for host and pathogen survival in acute and persistent viral infections. Proc Natl Acad Sci USA 101, 14560-14566.

[84] Easterbrook JD, Klein SL (2008). Immunological mechanisms mediating hantavirus persistence in rodent reservoirs. PLoS Pathog 4, e1000172.

[85] Hannah MF, Bajic VB, Klein SL (2008). Sex differences in the recognition of and innate antiviral responses to Seoul virus in Norway rats. Brain Behav Immun 22, 503-516.

[86] Geimonen E, Neff S, Raymond T, Kocer SS, Gavrilovskaya IN, Mackow ER. (2002). Pathogenic and nonpathogenic hantaviruses differentially regulate endothelial cell responses. Proc Natl Acad Sci USA 99, 13837-13842.

[87] Kraus AA, Raftery MJ, Giese T, Ulrich R, Zawatzky R, Hippenstiel S, Suttorp N, Kruger DH, Schonrich G. (2004). Differential antiviral response of endothelial cells after infection with pathogenic and nonpathogenic hantaviruses. J Virol 78, 6143-6150.

[88] Easterbrook JD, Klein SL. (2008). Corticosteroids modulate Seoul virus infection, regulatory T-cell responses and matrix metalloprotease 9 expression in male, but not female, Norway rats. J Gen Virol 89, 2723-2730.

[89] Klein SL, Bird BH, Glass GE. (2000). Sex differences in Seoul virus infection are not related to adult sex steroid concentrations in Norway rats. J Virol 74, 8213-8217.

[90] Jin HK, Yoshimatsu K, Takada A, Ogino M, Asano A, Arikawa J, Watanabe T. (2001). Mouse Mx2 protein inhibits hantavirus but not influenza virus replication. Arch Virol 146, 41-49.

[91] Dohmae K, Okabe M, Nishimune Y. (1994). Experimental transmission of hantavirus infection in laboratory rats. J Infect Dis 170, 1589-1592.

[92] Araki K, Yoshimatsu K, Lee BH, Kariwa H, Takashima I, Arikawa J. (2004). A new model of Hantaan virus persistence in mice: the balance between HTNV infection and $\mathrm{CD}^{+}$T-cell responses. Virology 322, 318-327. 
[93] Belkaid Y. (2007). Regulatory T cells and infection: a dangerous necessity. Nat Rev Immunol 7, 875-888.

[94] Schountz T, Prescott J. (2014). Hantavirus immunology of rodent reservoirs: current status and future directions. Viruses 6, 13171335.

[95] Schountz T, Prescott J, Cogswell AC, Oko L, Mirowsky-Garcia K, Galvez AP, Hjelle B. (2007). Regulatory T cell-like responses in deer mice persistently infected with Sin Nombre virus. Proc Natl Acad Sci USA 104, 15496-15501.

[96] Mosmann TR, Coffman RL. (1989). TH1 and TH2 cells: different patterns of lymphokine secretion lead to different functional properties. Annu Rev Immunol 7, 145-173.

[97] Farrar JD, Ouyang W, Lohning M, Assenmacher M, Radbruch A, Kanagawa O, Murphy KM. (2001). An instructive component in T helper cell type 2 (Th2) development mediated by GATA-3. J Exp Med 193, 643-650.

[98] Campbell DJ, Ziegler SF. (2007). FOXP3 modifies the phenotypic and functional properties of regulatory T cells. Nat Rev Immunol 7, 305-310.

[99] Zhao DM, Thornton AM, DiPaolo RJ, Shevach EM. (2006). Activated $\mathrm{CD}^{+} \mathrm{CD} 25^{+} \mathrm{T}$ cells selectively kill B lymphocytes. Blood 107, 3925-3932.

[100] Sakaguchi S, Wing K, Onishi Y, Prieto-Martin P, Yamaguchi T. (2009). Regulatory $T$ cells: how do they suppress immune responses? Int Immunol 21, 1105-1111.

[101] Raftery MJ, Kraus AA, Ulrich R, Krüger DH, Schönrich G. (2002). Hantavirus infection of dendritic cells. J Virol 76, 10724-10733.

[102] Botten J, Mirowsky K, Kusewitt D, Ye C, Gottlieb K, Prescott J, Hjelle B. (2003). Persistent Sin Nombre virus infection in the deer mouse (Peromyscus maniculatus) model: sites of replication and strand-specific expression. $J$ Virol 77, 1540-1550.

[103] Borucki MK, Boone JD, Rowe JE, Bohlman MC, Kuhn EA, DeBaca R, St Jeor SC. (2000). Role of maternal antibody in natural infection of Peromyscus maniculatus with Sin Nombre virus. J Virol 74, 2426-2429.

[104] Kallio ER, Poikonen A, Vaheri A, Vapalahti O, Henttonen H, Koskela E, Mappes T. (2006). Maternal antibodies postpone hantavirus infection and enhance individual breeding success. Proc Biol Soc 273, 2771-2776.

[105] Ashwell JD, Lu FW, Vacchio MS. (2000). Glucocorticoids in T cell development and function. Annu Rev Immunol 18, 309-345.

[106] Refojo D, Liberman AC, Holsboer F, Arzt E. (2001). Transcription factormediated molecular mechanisms involved in the functional cross-talk between cytokines and glucocorticoids. Immunol Cell Biol 79, 385-394.

[107] Rhen T, Cidlowski JA. (2005). Antiinflammatory action of glucocorticoids - new mechanisms for old drugs. $N$ Engl J Med 353, 1711-1723.

[108] Rutella S, Danese S, Leone G. (2006). Tolerogenic dendritic cells: cytokine modulation comes of age. Blood 108, 1435-1440.

[109] Sternberg EM. (2006). Neural regulation of innate immunity: A coordinated nonspecific host response to pathogens. Nat Rev Immunol 6, 318-328.

[110] Baschant U, Tuckermann J. (2010). The role of the glucocorticoid receptor in inflammation and immunity. J Steroid Biochem Mol Biol 120, 69-75.

[111] Ahsan MR, Al-Rafat AM, Sobhani ME, Molla MAW. (2013). Biomolecular basis of the role of chronic psychological stress hormone "glucocorticoid" in alteration of cellular immunity during cancer. Memo - Magazine of European Medical Oncology 6, 127-136.

[112] Ramírez F, Fowell DJ, Puklavec M, Simmonds S, Mason D. (1996). Glucocorticoids promote a TH2 cytokine response by $\mathrm{CD}^{+}$T cells in vitro. J Immunol 156, 2406-2412.

[113] Gratchev A, Kzhyshkowska J, Utikal J, Goerdt S. (2005). Interleukin-4 and dexamethasone counterregulate extracellular matrix remodelling and phagocytosis in type-2 macrophages. Scand J Immunol 61, 10-17.

[114] Bailey MT, Avitsur R, Engler H, Padgett DA, Sheridan JF. (2004). Physical defeat reduces the sensitivity of murine splenocytes to the suppressive effects of corticosterone. Brain Behav Immun 18, 416424.

[115] Gratchev A, Kzhyshkowska J, Kannookadan S, Ochsenreiter M, Popova A, Yu X, Mamidi S, Stonehouse-Usselmann E, MullerMolinet I, Gooi LM, Goerdt S. (2008). Activation of a TGF- $\beta$ specific multistep gene expression program in mature macrophages requires glucocorticoid-mediated surface expression of TGF- $\beta$ receptor II. J Immunol 180, 6553-6565.

[116] Ruzek MC, Pearce BD, Miller AH, Biron CA. (1999). Endogenous glucocorticoids protect against cytokine-mediated lethality during viral infection. J Immunol 162, 3527-3533.

[117] Bailey M, Engler H, Hunzeker J, Sheridan JF. (2003). The hypothalamic-pituitary-adrenal axis and viral infection. Viral Immunol 16, 141-157.

[118] Huggins JW, Kim GR, Brand OM, McKee KT Jr. (1986). Ribavirin therapy for Hantaan virus infection in suckling mice. $J$ Infect Dis 153, 489-497.

[119] Huggins JW, Hsiang CM, Cosgriff TM, Guang MY, Smith JI, Wu ZO, LeDuc JW, Zheng ZM, Meegan JM, Wang QN, Oland DD, Gui XE, Gibbs PH, Yuan GH, Zhang TM. (1991). Prospective, double-blind, concurrent, placebo-controlled clinical trial of intravenous ribavirin therapy of hemorrhagic fever with renal syndrome. J Infect Dis 164, 1119-1127.

[120] Severson WE, Schmaljohn CS, Javadian A, Jonsson CB. (2003). Ribavirin causes error catastrophe during Hantaan virus replication. $J$ Virol 77, 481-488.

[121] Chapman LE, Mertz GJ, Peters CJ, Jolson HM, Khan AS, Ksiazek TG, Koster FT, Baum KF, Rollin PE, Pavia AT, Holman RC, Christenson JC, Rubin PJ, Behrman RE, Bell LJ, Simpson GL, Sadek RF. (1999). Ribavirin Study Group: intravenous ribavirin for hantavirus pulmonary syndrome. Safety and tolerance during 1 year of open-label experience. Antivir Ther 4, 211-219.

[122] Chapman LE, Ellis BA, Koster FT, Sotir M, Ksiazek TG, Mertz GJ, Rollin PE, Baum KF, Pavia AT, Christenson JC, Rubin PJ, Jolson HM, Behrman RE, Khan AS, Bell LJ, Simpson GL, Hawk J, Holman RC, Peters CJ. (2002). Ribavirin Study Group: discriminators between hantavirus-infected and -uninfected persons enrolled in a trial of intravenous ribavirin for presumptive hantavirus pulmonary syndrome. Clin Infect Dis 34, 293-304.

[123] Vapalahti K, Virtala A, Vaheri A, Vapalahti O. (2010). Casecontrol study on Puumala virus infection: smoking is a risk factor. Epidemiol Infect 138, 576-584.

[124] Piyasirisilp S, Schmeckpeper BJ, Chandanayingyong D, Hemachudha T, Griffin DE. (1999). Association of HLA and Tcell receptor gene polymorphisms with Semple rabies vaccineinduced autoimmune encephalomyelitis. Ann Neurol 45, 595-600.

[125] Park K, Kim CS, Moon KT. (2004). Protective effectiveness of hantavirus vaccine. Emerg Infect Dis 10, 2218-2220.

[126].Schmaljohn C. (2009). Vaccines for hantaviruses. Vaccine 27, Suppl 4, D61-D64.

[127] Chu YK, Jennings GB, Schmaljohn CS. (1995). A vaccinia virusvectored Hantaan virus vaccine protects hamsters from challenge with Hantaan and Seoul viruses but not Puumala virus. J Virol 69, 6417-6423.

[128] Hooper JW, Custer DM, Thompson E, Schmaljohn CS. (2001). DNA vaccination with the Hantaan virus $M$ gene protects hamsters against three of four HFRS hantaviruses and elicits a high-titer neutralizing antibody response in Rhesus monkeys. $J$ Virol 75, 8469-8477.

[129] Hammerbeck CD, Hooper JW. (2010). Hantavirus vaccines. In: New Generation Vaccines, MM Levine, ed. (New York: Informa Healthcare), pp. 905-913.

[130] Hooper JW, Josleyna M, Ballantyneb J, Brocato R. (2013). A novel Sin Nombre virus DNA vaccine and its inclusion in a candidate pan-hantavirus vaccine against hantavirus pulmonary syndrome (HPS) and hemorrhagic fever with renal syndrome (HFRS). Vaccine 31, 4314- 4321.

[131] Akhmatova NK, Yusupova RS, Khaiboullina SF, Sibiryak SV (2003). Lymphocyte apoptosis during hemorrhagic fever with renal syndrome. Russian J Immunol 8, 37-46. 